\title{
O RECENTĂ ACHIZIŢIE A MUZEULUI NATIONAL DE ISTORIE A ROMÂNIEI: UN VAS DE TIP PHIALA
}

George TROHANI

\section{UNE RECENTE ACQUISITION DU MUSEE NATIONAL D'HISTOIRE DE LA ROUMANE - UN VASE DE TIP PHIALE}

Récemment, dans les collections du Musée National d'Histoire de la Roumanie est entré une pièce d'exception -un vase de type phiale, en argent, découvert dans les alentours de la commune Măgurele, au sud-ouest de Bucarest. La phiale est décoré avec des cannelures-côtes et des signes punctiformes qui reproduisent un animal et des lettres. Le vase date, probablement, du IIIe siècle av. J.C.

MOTS CLEFS : Gètes, phiale argent

CUVINTE CHEIE: geți, phiala din argint

Relativ recent Muzeul Naţional de Istorie a României a intrat în posesia unei piese de excepţie. Dată fiind frumuseţea şi importanţa ei o vom prezenta în cele urmează!'.

Este vorba despre un mic vas de tip phiala, din argint, descoperit, după spusele donatorului, de un grup de copii în preajma comunei Măgurele, situată la sud-vest de Bucureşti (Pl. 1).

Vasul are o înălţime de $3,9 \mathrm{~cm}$. Gura vasului este largă, rotundă, având un diametru la exterior de $9,9 \mathrm{~cm}$. Buza este rotunjită şi puţin evazată spre exterior, iar la interior prezintă un prag. Partea superioară a corpului, înaltă de $2,75 \mathrm{~cm}$, este tronconică cu pereţii arcuiţi. Unirea cu partea inferioară se face printr-o zonă carenată ce constituie diametrul maxim, ce are $7,6 \mathrm{~cm}$ la exterior. Partea inferioară, înaltă de $0,85 \mathrm{~cm}$, are forma unui trunchi de sferă. Corpul se sprijină pe un picior inelar, înalt de $0,3 \mathrm{~cm}$ şi cu diametrul de $3,45 \mathrm{~cm}$. Grosimea pereţilor vasului variază de la $0,2 \mathrm{~cm}$, în dreptul buzei, la 0,4 $\mathrm{cm}$ la mijlocul părţii inferioare a corpului, pentru ca în centrul aceleiaşi părţi inferioare să fie de $0,25 \mathrm{~cm}$.

Cele trei părţi ale vasului — partea superioară a corpului, cea inferioară şi

\footnotetext{
${ }^{1}$ Piesa a fost prezentată, pentru prima dată, la Colocviul internaţional dedicat regretatului arheolog Eugen Comşa, la împlinirea a 85 de ani de viață, octombrie 2008 .
}

piciorul inelar- par a fi lucrate separat şi apoi sudate.

La exterior vasul este decorat cu caneluri-coaste foarte dese. Partea superioară a corpului este divizată în opt registre relativ egale, despărţite între ele, alternativ, printr-un romb şi o ovă ascuţită în partea de sus şi cea de jos, dispuse vertical. Orizontal, spaţiul dintre ove este împărţit, la rândul său, pe jumătate, printr-o linie incizată. Câte o linie incizată delimitează, sus şi jos, spaţiul decorat constituit din acele caneluri-coaste ce sunt paralele cu laturile celor două romburi.

Zona de deasupra unuia dintre romburi prezintă o deteriorare recentă, gen tăietură, ce constituie punct de reper pentru descrierea decorului, în sensul că registrul superior, dintre rombul nr. 1 şi ovele nr. 1 şi 4 , are la stânga rombului, spre ova nr. 4,19 caneluricoaste, iar la dreapta rombului, spre ova nr. 1, 20 de astfel de caneluri-coaste. În schimb registrul inferior conţine la stânga 20 de caneluri-coaste, iar la dreapta 19, adică invers decât cel superior.

Spaţiul dintre ovele nr. 1 şi 2 este înjūmătăţit, la rândul său, de rombul nr. 2 . Astfel, între ova nr. 1 și rombul nr. 2, atât în registrul superior, cât şi în cel inferior sunt doar 17 caneluri-coaste. În schimb, între rombul nr. 2 şi ova nr. 2 sunt în registrul superior 21 de caneluri-coaste, iar în cel inferior 18.

Spaţiul dintre ovele nr. 2 și 3 cuprinde între ova nr. 2 şi rombul nr. 3 în registrul 
superior 21 de caneluri-coaste, iar în registrul inferior 20. Între rombul nr. 3 şi ova nr. 3 sunt în registrul superior 20 caneluri-coaste, iar în cel inferior 19.

Spaţiul dintre ovele nr. 3 şi 4 cuprinde în registrul superior între ova nr. 3 şi rombul nr. 4 un număr de 23 caneluri-coaste, iar între rombul nr. 4 şi ova nr. 4 se află 20 caneluricoaste. În schimb, în registrul inferior, între ova nr. 3 şi rombul nr. 4 se află 20 de caneluri-coaste, iar între rombul nr. 4 şi ova nr. 4 doar 19 caneluri-coaste.
Partea inferioară a corpului este şi ea decorată cu un număr de 86 caneluri-coaste situate între o linie incizată trasată sub diametrul maxim și până în piciorul-fund inelar.

În eventualitatea unor interpretări viitoare, pentru care în prezent nu vedem decât măiestria argintarului, redăm în tabelul de mai jos situaţia constată şi enunţată mai sus, dar doar pentru partea superioară a corpului.

\begin{tabular}{|l|c|c|c|c|c|c|c|c|}
\hline & $\begin{array}{c}\text { Romb 1 } \\
\text { ova 1 }\end{array}$ & $\begin{array}{c}\text { ova 1 - } \\
\text { romb 2 }\end{array}$ & $\begin{array}{c}\text { Romb 2 } \\
\text { - ova 2 }\end{array}$ & $\begin{array}{c}\text { ova 2 - } \\
\text { romb 3 }\end{array}$ & $\begin{array}{c}\text { Romb 3 } \\
\text { ova 3 }\end{array}$ & $\begin{array}{c}\text { ova 3 - } \\
\text { romb 4 }\end{array}$ & $\begin{array}{c}\text { Romb 4 } \\
\text { - ova 4 }\end{array}$ & $\begin{array}{c}\text { Ova 4 - } \\
\text { romb 1 }\end{array}$ \\
\hline $\begin{array}{l}\text { Reg. } \\
\text { Sup. }\end{array}$ & 20 & 17 & 21 & 21 & 20 & 23 & 20 & 19 \\
\hline $\begin{array}{l}\text { Reg. } \\
\text { Inf. }\end{array}$ & 19 & 17 & 18 & 20 & 19 & 20 & 19 & 20 \\
\hline
\end{tabular}

Fundul vasului, adică spaţiul cuprins în interiorul cercului format de piciorul inelar este drept şi bine cizelat. În centrul său se află o adâncitură rotundă provenită probabil de la suportul pe care a fost prelucrat vasul într-o primă fază. În schimb, chiar pe marginea spaţiului liber de lângă piciorul inelar sunt redate, punctiform, cu ajutorul unui punctator foarte fin, diferite figuri şi semne.

De la stânga spre dreapta se observă mai întâi conturul unui animal, ce pare a fi un iepure alergând. Corpul şi capul sunt două ovale tangente, corpul mai mare, iar capul mai mic. În faţă sunt două picioare cel din stânga redat prin 5 puncte, iar cel din dreapta prin 3 . În spate este doar un picior din 5 puncte, sub el aflându-se un mic pătrat redat prin şase puncte. Iepurele aleargă spre o figură ce ar putea reprezenta un copac sau, mai curând, litera A mare de mână, urmată, la relativ mică distanţă, de două linii verticale, paralele - eventual 2 de I, primul redat prin 6 puncte, iar al doilea prin 7. Urmează, puţin mai departe, un $\mathrm{P}$, un S şi o mică linie orizontală formată din 7 puncte. La o distanţă ceva mai mare se află un $\mathrm{P}$ sau poate un $\mathrm{R}$, apoi iarăşi două linii verticale şi paralele - prima din 3 puncte, următoarea doar din 2 . La distanţă iarăşi un eventual $\mathrm{P}$, un $\mathrm{S}$ şi în final 3 puncte dispuse fără ordine.

Vasul a fost supus şi unei analize fizico-chimice de către colegul fizician $\mathrm{dl}$. Gheorghe Niculescu care a constat următoarea componentă metalică :

\begin{tabular}{|c|c|c|}
\hline & Interior corp & Interior buză \\
\hline Argint & $94,16 \% * 0,34$ & 93,72 \\
\hline Cupru & $5,36 \% * 0,12$ & 5,00 \\
\hline Plumb & $0,48 \%{ }^{*} 0,03$ & 0,49 \\
\hline Staniu & & 0,79 \\
\hline
\end{tabular}

Acestea sunt datele de care dispunem până în prezent privind această eventuală descoperire fortuită. În privinţa datării rezolvarea problemei ar fi eventual simplă. Zona Măgurele ar putea reprezenta nordul arealului cu descoperiri din secolele IV-III a. Chr. reprezentat de punctele Bălănoaia (cazan de bronz), Daia (locuire), Chirnogi (mormânt cu caracter princiar), Căscioarele (locuire) sau estul aceluiaşi areal cu descoperirile de la 
Peretu (mormânt princiar), Zimnicea (locuire şi necropolă), Făcău (mormânt cu caracter princiar), Popeşti (locuire) etc. Descoperirile menţionate fiind arhicunoscute în rândul specialiştilor nu credem că trebuie fácută o trimitere bibliografică.

Decorul cu caneluri-coaste este deseori întâlnit pe vasele de tip phiala din argint, atât de la Peretu, cât şi de la Agighiol, Rogozen (Bulgaria) etc. Vasul de la Măgurele, prin dimensiuni, formă şi decor ar putea data, după părerea noastră, din secolul III a. Chr., fiind un produs ceva mai recent decât descoperirile amintite mai sus.

Ceea ce în prezent este încă inexplicabil sunt semnele redate punctat de pe fundul vasului care se aseamănă cu literele din alfabetul latin şi nu grecesc, ceea ce este inexplicabil. Au fost eventual făcute ulterior sau ţin tot de măiestria argintarului. Întrebarea rămâne, pentru moment, fără răspuns. Am dorit însă să punem în circuitul științific această piesă pentru ca eventuale date viitoare să ne poată lămuri mai bine.

Pl. 1 - Vas phiala din argint, de la Măgurele

Pl. 1 - Vase de type phiale en argent, de Măgurele

\section{George TROHANI}

Muzeul Naţional de Istorie a României

Secția Arheologie

Calea Victoriei 12, 030026, București.

gtrohani@yahoo.com 


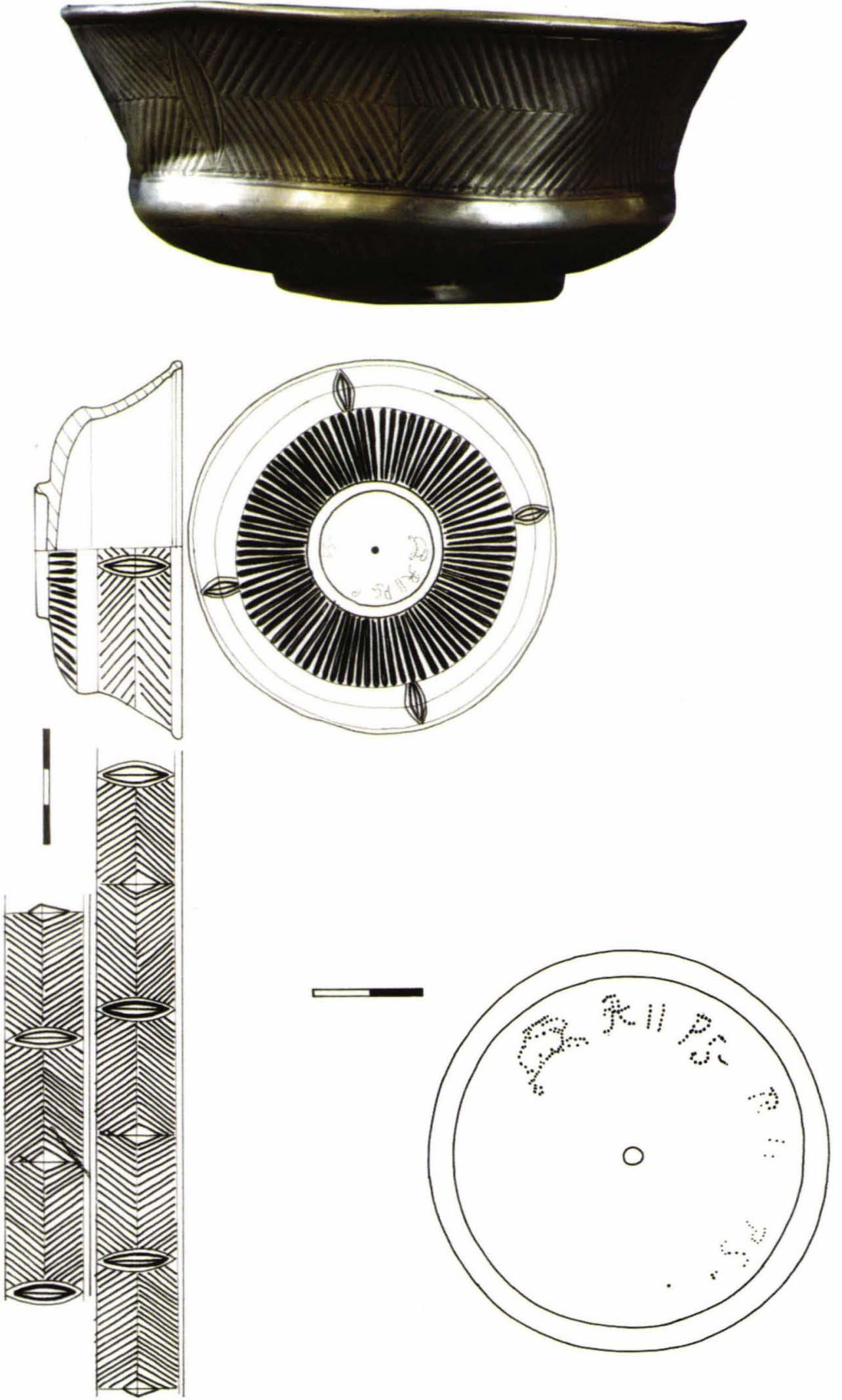

PI. 1 - Vas de tip phiala din argint, de la Măgurele. 
